\title{
Pengaruh Stres Kerja, Tekanan Pekerjaan dan Keletihan Kerja terhadap Kinerja Karyawan pada Bank BRI Wilayah Muara Bulian
}

\author{
Etty Siswati ${ }^{1}$, Ratna \\ STIE Graha Karya Muara Bulian ${ }^{1}$
}

\begin{abstract}
The aim of this study to know the effect of job stress, job pressure and job fatigue on employee performance at BNK BRI of Muara Bulian Are. Data collecting used survey method, that is to obtain information from respondents by using interview techniques and spreading the list of questions and to measureit by using Likert scale. Population of the research is employees at BANK BRI of Muara Bulian Area. Analyzer used is multiple linear regression, this method using computer assistance through program SPSS 20.0 for windows. From the calculation of SPSS 20.0 , it found that is the job stress variable is 2,193, because $t_{\text {count }}>$ from $t_{\text {table }},(2,193>1.68195$ hence Ho accepted and Ha rejected, it means that independent variable has influence to dependent variable, which means there is partial influence between job stress to employees performance at Bank BRI of MuaraBulian Area.Variable job pressure of 0.254, Because $t_{\text {count }}<$ of $t_{\text {table, }}(0.254<1.68195) \mathrm{Ha}$ is accepted and Ho is rejected, it means that independent variable has no influence on dependent variable, meaning there is no partial influence between job pressure on employee performance at Bank BRI of Muara Bulian Area.Job fatigue variable is 9.461 Because to $t_{\text {count }}>$ from $t_{\text {table, }}(9.461>1.68195)$ then Ha accepted and Ho accepted, Ha rejected means that the independent variable has influence on the dependent variable, which means there is partial influence between job fatigue on employee performance on Bank BRI of Muara Bulian Area.
\end{abstract}

Keywords: Job stress, Job pressure and Job fatigue, Employee performance

\section{PENDAHULUAN}

Persaingan dan tuntutan profesionalitas yang semakin tinggi menimbulkan banyaknya tekanan-tekanan yang harus dihadapi individu dalam lingkungan kerja.Selain tekanan yang berasal dari lingkungan kerja, lingkungan keluarga dan lingkungan sosial juga sangat berpotensial menimbulkan kecemasan.Dampak yang sangat merugikan dari adanya gangguan kecemasan yang sering dialami oleh masyarakat dan karyawan khususnya disebut stres.Stres terhadap kinerja dapat berperan positif dan juga berperan negatif, seperti dijelaskan pada "Hukum Yerkes Podson (1904) yang menyatakan hubungan antara stres dengan kinerja seperti huruf U terbalik". (Mas'ud, 2002:20).
Sasono (2004:5) mengungkapkan bahwa stres mempunyai dampak positif dan negatif. Dampak positif stres pada tingkat rendah sampai pada tingkat moderat bersifat fungsional dalam arti berperan sebagai pendorong peningkatan kinerja karyawan.Sedangkan pada dampak negatif stres tingkat yang tinggi adalah penurunan pada kinerja karyawan yang drastis.

Stres kerja merupakan aspek yang penting bagi perusahaan terutama keterkaitannya dengan kinerja karyawan.Perusahaan harus memiliki kinerja, kinerja yang baik/tinggi dapat membantu perusahaan untuk memperoleh keuntungan.Sebaliknya, bila kinerja menurun dapat merugikan perusahaan. Oleh karenanya kinerja karyawan perlu memperoleh perhatian antara lain dengan

Pengaruh Stres Kerja, Tekanan Pekerjaan dan Keletihan Kerja terhadap Kinerja Karyawan pada Bank BRI Wilayah Muara Bulian 
jalan melaksanakan kajian berkaitan dengan variabel stres kerja.

Bahaya stres diakibatkan karena kondisi kelelahan fisik, emosional dan mental yang disebabkan oleh adanya keterlibatan dalam waktu yang lama dengan situasi yang menuntut secara emosional. Proses berlangsung secara bertahap, akumulatif, dan lama kelamaan menjadi semakin memburuk.

Dalam jangka pendek, stres yang dibiarkan begitu saja tanpa penanganan yang serius dari pihak perusahaan membuat karyawan menjadi tertekan, tidak termotivasi, dan frustasi menyebabkan karyawan bekerja tidak optimal sehingga kinerjanya pun akan terganggu. Dalam jangka panjang, karyawan tidak dapat menahan stres kerja maka ia tidak mampu lagi bekerja diperusahaan. Pada tahap yang semakin parah, stres bisa membuat karyawan menjadi sakit atau bahkan akan mengundurkan diri (turnover). Artinya, stres muncul saat karyawan tidak mampu memenuhi apa yang menjadi tuntutantuntutan pekerjaan yang kemudian menjadi tekanan terhadap dirinya sendiri. Apabila karyawan mengalami stress kerja, maka dapat berpengaruh terhadap psikis karyawan di kantor.

Dampak dari tekanan kerja ini ialah sulitnyaberkonsentrasi ketika diberi pekerjaan dan mudah lelah. Hal ini yang akan menggangu terhambatnya proses kinerja karyawan di kantor.Ketika karyawan menghadapi tekanan yang tinggi maka energi yang ada pada karyawan akantercurah untuk menghadapi tekanan tersebut, sehingga energi karyawan untuk bekerja semakin berkurang dan kinerja yang dilakukan karyawan menjadi lebihjelek. Apabila kinerja karyawan jelek, maka hasil pekerjaan akan menjadi tidak maksimal, bahkan terkesan asal-asalan

Tekanan kerja yang tinggi akan menyebabkan menurunnya kinerja karyawan sehingga dapat mengakibatkan menurunnya moral kerja, kedisiplinan, prestasi kerja, dan menurunnya tingkat kualitas kerja karena pekerjaan tidak dikerjakan dengan sepenuh hati oleh karyawannya. Fenomena yang terjadi di Bank BRI Muara Bulian terkait kinerja karyawan, bahwa tekanan kerja di Bank BRI Muara Bulian sangat banyak dan harus selesai dalam sehari sehingga mengakibatkan kelelahan fisik, emosional dan mental. Proses ini secara perlahan dirasakan terus menerus oleh karyawan dan bersifat akumulatif Akhirnya kinerja karyawan di. Bank BRI mengalami kenaikan dan penurunan.

Akibat dari kelelahan fisik bagi setiap orang memiliki arti tersendiri dan bersifat subyektif, lelah adalah aneka keadaan yang disertai penurunan efisiensi dan ketahanan dalam bekerja, kelelahan merupakan perlindungan mekanisme tubuh agar tubuh menghindari kerusakan lebih lanjut, sehingga terjadilah pemulihan.

Menurut Cameron kelelahan kerja merupakan kriteria yang kompleksyang tidak hanya menyangkut kelelahan fisiologis dan psikologis tetapi dominan hubungannya dengan penurunan kinerja fisik, adanya perasaan lelah, penurunan motivasi dan penurunan produktivitas kerja.

Bank BRI adalah salah satu bank milik pemerintah yang terbesar di Indonesia. Pada awalnya Bank Rakyat Indonesia (BRI) didirikan di Purwokerto, Jawa Tengah oleh Raden Bei Aria Wirjaatmadja dengan nama De Poerwokertosche Hulp en Spaarbank der Inlansche Hoofden atau "Bank Bantuan dan Simpanan Milik Kaum Priyayi Purwokerto'. Suatu lembaga keuangan yang melayani orang-orang berkebangsaan Indonesia (Pribumi). Lembaga tersebut berdiri tanggal 16 Desember 1895 yang kemudian dijadikan sebagai hari lahir BRI.

Sebagai manusia biasa, karyawan pada Bank BRI tentunya dihadapkan dengan kondisi dilematis. Di satu sisi mereka harus 
bekerja untuk focus pada visi perusahaan yaitu memberi kepuasan bagi pelanggan sementara disisi lain mereka sebagai karyawan memiliki kebutuhan dan keinginan yang perlu mendapat perhatian dari perusahaan. Sedangkan daya tahan setiap karyawan tentunya berbeda beda, Kondisi seperti ini tentunya akan menimbulkan stres kerja, tekanan pekerjaan dan juga keletihan kerja bagi karyawan.

Oleh sebab itu penting bagi perusahaan Bank BRI Muara Bulian untuk memenuhi kebutuhan karyawan dan menciptakan kenyamanan kerja sehingga sangat tidak mungkin untuk terkena stres.Stres pekerjaan dapat diartikan sebagai tekanan yang dirasakan karyawan karena tugas-tugas pekerjaan tidak dapat mereka penuhi.

Berdasarkan latar belakang, maka dapat dirumuskan masalah dari penelitian sebagai berikut: 1) Bagaimana Pengaruh Stress Kerja terhadap Kinerja Karyawan pada Bank BRI Muara Bulian. 2) Bagaimana Pengaruh Tekanan Pekerjaan terhadap Kinerja Karyawan pada Bank BRI Muara Bulian. 3) Bagaimana Pengaruh Keletihan Kerja terhadap Kinerja Karyawan pada Bank BRI Muara Bulian. 4) Bagaimana pengaruh Stress Kerja, Tekanan Pekerjaan dan Keletihan Kerja terhadap Kinerja Karyawan pada Bank BRI Muara Bulian.

Berdasarkan rumusan masalah diatas, maka tujuan penelitian yang hendak dicapai: 1) Untuk mengetahui Pengaruh Sress Kerja terhadap Kinerja Karyawan pada Bank BRI Muara Bulian. 2) Untuk mengetahui Pengaruh Tekanan Pekerjaan terhadap Kinerja Karyawan pada Bank BRI Muara Bulian. 3) Untuk mengetahui Pengaruh Keletihan Kerja Kinerja Karyawan pada Bank BRI Muara Bulian. 4) Untuk mengetahui Pengaruh Stress Kerja, Tekanan Pekerjaan dan Keletihan Kerja terhadap Kinerja Karyawan pada Bank BRI Muara Bulian.

\section{METODE PENELITIAN}

Penelitian kuantitatif yang berbentuk asosiatif disini digunakan untuk menulis pengaruh antara dua variabel atau lebih. Penelitian dilakukan di Bank BRI Muara Bulian. Likasi penelitian ini dipilih karena ditemukan masalah-masalah yang berhubungan dengan stress kerja, tekanan pekerjaan, keletihan kerja pada Bank BRI Muara Bulian.

Jenis penelitian yang dikemukakan dalam penelitian ini adalah bersifat deskriptif kuantitatif. Sedangkan jenis penelitian studi kasus yang didukung dengan mengumpulkan informasi melalui wawancara dan pemberian kuesioner kepada responden.

Analisis regresi linier berganda berfungsi untuk mengukur kekuatan hubungan antara variable indevenden (Stres kerja, tekanan pekerjaan, keletihan kerja) dengan variable dependen (Produktivitas kerja karyawan) pada Bank BRI Muara Bulian.

\section{HASIL DAN PEMBAHASAN \\ Hasil Uji Validitas dan Uji Reliabilitas}

Hasil pengujian instrument dalam penelitian ini menujukan bahwa seluruh Item na intrumen dinyatakan valid karena koofisien korelasi dengan butir sekor lebih besar dari 0,2483. Hasil dari uji Reabilitas menujukan bahwa nilai Cronbach's Alpa untuk setiap variabel lebih besar dari 0,6 sehingga dinyatakan memenuhi syarat reabilitas atau dapat dikatakan reliabel.

\section{Analisis Regresi Linier Berganda}

Analisis yang dapat dipakai penelitian ini adalah regresi linier berganda. Analisis dipakai guna memberitahukan adanya pengaruh variable bebas yaitu Stres Kerja $\left(\mathrm{X}_{1}\right)$, Tekanan Pekerjaan $\left(\mathrm{X}_{2}\right)$, keletihan Kerja $\left(\mathrm{X}_{3}\right)$, terhadap Kinerja Karyawan $(\mathrm{Y})$. 
Coefficients $^{\mathrm{a}}$

\begin{tabular}{|c|c|c|c|c|c|c|}
\hline \multirow{2}{*}{\multicolumn{2}{|c|}{ Model }} & \multicolumn{2}{|c|}{ Unstandardized Coefficients } & \multirow{2}{*}{$\begin{array}{c}\begin{array}{c}\text { Standardized } \\
\text { Coefficients }\end{array} \\
\text { Beta }\end{array}$} & \multirow[t]{2}{*}{$\mathrm{t}$} & \multirow[t]{2}{*}{ Sig. } \\
\hline & & B & Std. Error & & & \\
\hline \multirow{4}{*}{1} & (Constant) & 5.781 & 3.386 & & 1.707 & .096 \\
\hline & $\mathrm{X} 1$ & .164 & .075 & .173 & 2.193 & .034 \\
\hline & $\mathrm{X} 2$ & .022 & .088 & .019 & .254 & .801 \\
\hline & X3 & .596 & .063 & .803 & 9.467 & .000 \\
\hline
\end{tabular}

a. Dependent Variable: Y

Dari hasil SPSS diperoleh model regresi sebagai berikut :

$Y=5.781+0,164 X_{1}+0,22 X_{2}+0,596 X_{3}$

Interpretasi dari regresi diatas adalah sebagai berikut :

1. Konstanta (a)

Ini berarti jika semua variabel bebas memiliki nilai nol (0) maka nilai variabel terikat sebesar 5.781

2. Stress $\left(X_{1}\right)$ terhadap Kinerja Karyawan (Y)

Nilai koefisien untuk variabel $\mathrm{X}_{1}$ sebesar 0,164 . Hal ini mengandung arti bahwa setiap kenaikan satu-satuan variabel stres maka variabel Kinerja Karyawan akan naik sebesar 0,164 dengan asumsi bahwa variabel bebas yang lain dari model regresi adalah tetap.

3. Tekanan Kerja $\left(X_{2}\right)$ terhadap Kinerja

Karyawan (Y)

Nilai koefficients untuk variabel tekanan kerja $\left(\mathrm{X}_{2}\right)$ sebesar 0,022 dan bertanda positif,. Hal ini mengandung arti bahwa setiap kenaikan variabel tekanan kerja satu satuan maka variabel Kinerja karyawan akan meningkat sebesar 0,022 dengan asumsi bahwa variabel bebas yang lain dari model regresi tetap.

4. Keletihan Kerja $\left(\mathrm{X}_{3}\right)$ terhadap Kinerja Karyawan (Y)

Nilai koefficients untuk variabel keletihan kerja $\left(\mathrm{X}_{2}\right)$ 0,596 dan bertanda positif,. Hal ini mengandung arti bahwa setiap kenaikan variabel tekanan kerja satu satuan maka variabel Kinerja Karyawan akan meningkat sebesar 0,596 dengan asumsi bahwa variabel bebas yang lain dari model regresi tetap.

\section{Uji t}

Dari tabel coeficients di atas dapat dilihat, perhitungan tersebut membandingkan antara $t_{\text {hitung }}$ dengan $t_{\text {tabel }}$, dengan taraf ketidak percayaan atau signifikansi sebesar $0,05 \%$ atau $5 \%$. $t_{\text {tabel }}$ dari penelitian ini didapat dari rumus $n-2$, jadi didapatlah $\mathrm{t}$ tabel sebesar 1.68195

Berikut uraian pengaruh dari setiap variabel independent terhadap variabel dependent.

1. Dari hasil perhitungan menggunakan program SPSS 20.00 pada tabel Coefficients $^{\text {a }}$ di atas. Dari hasil diatas didapatlah

2. Variabel stress kerja $\left(X_{1}\right) t_{\text {hitung }}$ sebesar 2.193, Dikarenakan $t_{\text {hitung }}>$ dari $t_{\text {tabel }}$, (2.193 > 1.68195 maka Ho diterima dan Ha ditolak, artinya bahwa variabel independen memiliki pengaruh terhadap variabel dependen, yang berarti ada pengaruh secara parsial antara stress terhadap kinerja karyawan pada Bank BRI Muara Bulian.

3. Variabel Tekanan kerja $\left(\mathrm{X}_{2}\right) \mathrm{t}_{\text {hitung }}$ sebesar 0.254, Dikarenakan thitung $<$ dari $t_{\text {tabel }}$, $(0.254<1.68195)$ maka Ha diterima dan Ho ditolak, artinya bahwa variabel independen tidak memiliki pengaruh 
terhadap variabel dependen, yang berarti tidak ada pengaruh secara parsial antara tekanan kerja terhadap kinerja karyawan pada Bank BRI Muara Bulian.

4. Variabel keletihan kerja $\left(\mathrm{X}_{3}\right) \mathrm{t}_{\text {hitung }}$ sebesar 9.461 Dikarenakan $t_{\text {hitung }}>$ dari $\mathrm{t}_{\text {tabel}},(9.461>1.68195)$ maka Ha diterima dan Ho diterima, Ha ditolak artinya bahwa variabel independen memiliki pengaruh terhadap variabel dependen, yang berarti tidak ada pengaruh secara parsial antara keletihan kerja terhadap kinerja karyawan pada Bank BRI Muara Bulian.

\section{Uji $\boldsymbol{F}$}

Uji ini digunakan untuk menari pengaruh secara simultan antara variabel independent terhadap variabel dependent, dengan menggunakan spss 20.00, maka di dapat hasil :

ANOVA ${ }^{a}$

\begin{tabular}{|c|c|c|c|c|c|}
\hline Model & Sum of Squares & $\mathrm{df}$ & Mean Square & $\mathrm{F}$ & Sig. \\
\hline Regression & 666.788 & 3 & 222.263 & 58.587 & $.000^{\mathrm{b}}$ \\
\hline Residual & 147.955 & 39 & 3.794 & & \\
\hline Total & 814.743 & 42 & & & \\
\hline
\end{tabular}

a. Dependent Variable: Y

b. Predictors: (Constant), $\mathrm{X}_{1}, \mathrm{X}_{2}, \mathrm{X}_{3}$

Pengujian secara simultan $\mathrm{X}_{1}, \mathrm{X}_{2}, \mathrm{X}_{3}$ terhadap $\mathrm{Y}$, dari tabel Anova di atas diperoleh nilai $t_{\text {hitung }}$ sebesar 1.226 dengan nilai probabilitas $(\mathrm{sig})=0,313$. Nilai $f_{\text {hitung }}$ $(58.586)<\mathrm{f}_{\text {tabel }}(2,85)$. Karena nilai $\mathrm{f}_{\text {hitung }}$ lebih kecil daripada $\mathrm{f}_{\text {tabel maka dapat }}$ disimpulkan bahwa variabel stress, tekanan pekerjaan dan keletihan kerja berpengaruh secara simultan terhadap kinerja karyawan pada Bank BRI Muara Bulian.

Koefisien Determinasi $\left(R^{2}\right)$

Koefisien Determinasi merupakan formula dalam mencari pengaruh suatu variabel terhadap variabel lainnya dalam satuan persentase, dari hasil perhitungan SPSS 20.00 dibawah ini :

Model Summary

\begin{tabular}{|l|r|r|r|r|}
\hline Model & \multicolumn{1}{|c|}{ R } & R Square & Adjusted R Square & Std. Error of the Estimate \\
\hline 1 & $.905^{\mathrm{a}}$ & .818 & .804 & 1.94775 \\
\hline
\end{tabular}

a. Predictors: (Constant), $\mathrm{X}_{1}, \mathrm{X}_{2}, \mathrm{X}_{3}$

Dari hasil ini didapatlah hasil dari $\mathrm{R}$ Square sebesar 804. Hasil $R$ square ini merupakan hasil dari Koefisien determinasi. Jadi secara persentase dapat disimpulkan bahwa persentase pengaruh variabel independent terhadap dependent adalah sebesar 80,4\%dan sisanya 19,6 \% dipengaruhi oleh variabel-variabel lain diluar model yang tidak dibahas didalam penelitian ini.

Dengan demikian secara keseluruhan dapat disimpulkan bahwa stres, tekanan pekerjaan dan keletihan karyawan pada Bank BRI Muara Bulian berpengaruh terhadap kinerja karyawan sebesar.

\section{SIMPULAN}


Berdasarkan hasil pembahasan, maka dapat ambil kesimpulan sebagai berikut :

1. Hasil pengujian hipotesis pertama Variabel Stress kerja $\left(\mathrm{X}_{1}\right)$ thitung sebesar 2.193, Dikarenakan $t_{\text {hitung }}>$ dari $t_{\text {tabel}}$, (2.193 > 1.68195 maka Ho diterima dan Ha ditolak, artinya bahwa variabel independen memiliki pengaruh terhadap variabel dependen, yang berarti ada pengaruh secara parsial antara stress terhadap kinerja karyawan pada Bank BRI Muara Bulian.

2. Hasil pengujian hipotesis kedua Variabel Tekanan kerja $\left(\mathrm{X}_{2}\right)$ thitung sebesar 0.254, Dikarenakan $t_{\text {hitung }}<$ dari $\mathrm{t}_{\text {tabel }},(0.254<$ 1.68195) maka $\mathrm{Ha}$ diterima dan $\mathrm{Ho}$ ditolak, artinya bahwa variabel independen tidak memiliki pengaruh terhadap variabel dependen, yang berarti tidak ada pengaruh secara parsial antara tekanan kerja terhadap kinerja karyawan pada Bank BRI Muara Bulian.

3. Hasil pengujian hipotesis tiga Variabel Keletihan kerja $\left(\mathrm{X}_{3}\right) \mathrm{t}_{\text {hitung }}$ sebesar 9.461 Dikarenakan $t_{\text {hitung }}>$ dari $t_{\text {tabel }},(9.461>$ 1.68195) maka $\mathrm{Ha}$ diterima dan $\mathrm{Ho}$ diterima, Ha ditolak artinya bahwa variabel independen memiliki pengaruh terhadap variabel dependen, yang berarti tidak ada pengaruh secara parsial antara keletihan kerja terhadap kinerja karyawan pada Bank BRI Muara Bulian.

4. Pengujian secara simultan $X_{1}, X_{2}, X_{3}$ terhadap $\mathrm{Y}$, dari tabel Anova di atas diperoleh nilai thitung sebesar 1.226 dengan nilai probabilitas $(\mathrm{sig})=0,313$. Nilai $f_{\text {hitung }}(58.586)<f_{\text {tabel }}(2,85)$. Karena nilai $\mathrm{f}_{\text {hitung }}$ lebih kecil daripada $\mathrm{f}_{\text {tabel }}$ maka dapat disimpulkan bahwa variabel stress, tekanan pekerjaan dan keletihan kerja berpengaruh secara simultan terhadap kinerja karyawan pada Bank BRI Muara Bulian.

\section{DAFTAR PUSTAKA}

Arikunto, Suharsimi. 2006. Prosedur Penelitian Suatu Pendekatan Praktik Edisi Revisi IV. Jakarta : PT. Asdi Mahasatya.

Alex S, Nitisemito,2002, Manajemen Personal,Ghalia Indonesia,Jakarta.

Anwar Prabu mangkunegara, 2008, Manajemen Sumber Daya Manusia Peusahaan, RemajaRosdakarya, bandung.

AS.Munadar.(2004), Peran Budaya Organisasi Dalam Peningkatan Kerja Perusahaan,PO Fakultas Psikologi UI.Depok.

Gibson, Ivancevich \& Donnelly, 2000, Organization, Berhavior, Structure, Processes, (tenth edition), Singapore: MCDraw-Hill Campanies.

Gallette dan Laderer (1989) Intrumen digunakan oleh Restuning dan Indriantoro (2000).

Ghozali, Imam. 2007. Aplikasi Analisis Multivariate Dengan Program SPSS. Semarang: BP Universitas Diponogoro

Hasibuan,Malayu.S.P.2006Manajemen

Sumber Daya Manusia. Bumi Aksar,Jakarta.

Handoko.T.Tani, 2001, Manajemen Personalia Dan Manusia, Edisi Kedua, Penerbit Andi.Yogyakarta.

Saydam, Gozali. 2005. Menajemen Sumber Daya Manusia Suatu Pendekatan Mikro. Cetakan III. Jakarta : Djambatan.

Sugiono, 2000.Metode Penelitian dan Bisnis.Alfabeta, Bandung.

Nitisemito. 2000. Manajemen Personalia. Jakarta : Ghalia Indonesia. 